\title{
PENGARUH UKURAN DAN CASH CONVERSION CYCLE TERHADAP PROFITABILITAS PERUSAHAAN
}

\author{
Beby Rama Telly ${ }^{1)}$ \\ Muslim Ansori 2) \\ Politeknik Negeri Batam \\ Jurusan Manajemen Bisnis, Program Studi Akuntansi \\ Jl Ahmad Yani, Batam Centre, Batam 29461, Indonesia \\ E-mail: telly19.beby@gmail.com ${ }^{1)}$ \\ Ansori.wae@gmail.com ${ }^{2}$
}

\begin{abstract}
Abstrak: Penelitian ini bertujuan untuk menganalisis pengaruh ukuran perusahaan dan Cash Conversion Cycle terhadap profitabilitas pada perusahaan manufaktur yang terdaftar di Bursa Efek Indonesia yang menerbitkan laporan keuangan tahun 2013-2015. Ukuran perusahaan dan Cash Conversion Cycle menjadi variabel Independen, sedangkan variabel dependen yaitu profitabilitas yang diukur dengan ROA (Return On Asset) Sugiono (2009). Hipotesis yang diajukan pada penelitian ini adalah ukuran perusahaan berpengaruh terhadap profitabilitas dan Cash Corversion Cycle berpengaruh terhadap profitabilitas. Data penelitian ini diperoleh dari laporan keuangan perusahaan yang diambil dari Bursa Efek Indonesia. Populasi penelitian ini adalah perusahaan manufaktur yang terdaftar di Bursa Efek Indonesia selama tahun 2013 2015. Penentuan sampel menggunakan metode purposive sampling dan sampel yang diperoleh sebanyak 261 perusahaan. Hipotesis dalam penelitian ini diuji menggunakan analisis regresi berganda. Hasil analisis menunjukkan bahwa hipotesis pertama yaitu ukuran perusahaan tidak berpengaruh terhadap profitabilitas perusahaan. Hipotesis kedua yaitu Cash Conversion Cycle berpengaruh terhadap profitabilitas.
\end{abstract}

Kata Kunci: Ukuran perusahaan, Cash Conversion Cycle, dan Profitabilitas

\section{PENDAHULUAN}

Semakin berkembangnya dunia usaha dewasa ini, maka persaingan antar perusahaan, khususnya antar perusahaan sejenis akan semakin ketat. Untuk menjaga kelangsungan hidup perusahaan dalam menghadapi persaingan yang ketat tersebut, maka diperlukan suatu penanganan dan pengelolaan sumber daya yang dilakukan oleh pihak manajemen dengan baik. Bagi pihak manajemen, selain dituntut untuk dapat mengkoordinasikan penggunaan sumber daya yang dimiliki oleh perusaan secara efektif dan efisien, juga dituntut untuk dapat menghasilkan keputusan - keputusan yang menunjang terhadap pencapaian tujuan perusahaan dimasa yang akan datang. Perusahaan ditargetkan untuk selalu selangkah lebih maju dari para pesaingnya agar dapat mencapai tujuan perusahaan, yaitu menghasilkan laba sebesar-besarnya demi mempertahankan kelangsungan hidup perusahaan yang disertai dengan memperbesar skala usahanya. Agar tercapainya tujuan tersebut maka perusahaan harus berkembang pada segala bidang untuk dapat mengikuti dan memenuhi kebutuhan pasar yang berubah-ubah. Bertambah besarnya perusahaan, perusahaan dituntut untuk semakin bijak dalam mengelola dana yang tersedia untuk menjalankan akitivitas operasional perusahaan.

Dana yang diinvestasikan untuk menjalankan aktivitas operasional perusahaan disebut sebagai modal kerja. Pada dasarnya modal kerja merupakan dana yang selalu berputar, dimana pada awalnya dikeluarkan untuk membiayai aktivitas operasional sehari-hari agar proses produksi dapat berjalan. Hasil produksi kemudian dijual sehingga perusahaan akan memperoleh 
diperoleh tersebut akan masuk kembali sebagai penanaman modal kerja perusahaan. Perputaran modal kerja ini akan terus terjadi selama perusahaan masih berjalan sehingga perusahaaan wajib melakukan evaluasi secara berkesinambunganpada siklus pengelolaan modal kerjanya.

Siklus modal kerja harus senantiasa dikelola dan di evaluasi agar tidak terlalu kecil maupun terlalu besar jumlahnya, Jika jumlahnya terlalu kecil maka perusahaan akan menghadapi kondisi llikuid, kondisi perusahaan kesulitan untuk memenuhi kewajiban lancarnya seperti pembayaran gaji karyawan, utang usaha dan lainlain yang disebabkan oleh tidak tersedianya dana yang cukup untuk melunasi utang jangka pendek perusahaan yang telah jatuh tempo. Apabila jumlah modal kerja terlalu besar, maka hal terebut dapat mengindikasi bahwa adanya dana yang tidak terpakai. Dana yang yang tidak terpakai tersebut secara tidak langsung akan mengurangi laba perusahaaan karena dana tersebut seharusnya dapat digunakan dalam berbagai macam kepentingan seperti pengembangan usaha maupun digunakan untuk membiayai investasi jangka pendek perusahaan.

Investasi jangka pendek perusahaan perlu dilakukan untuk memperoleh laba yang tinggi berdasarkan keefektifan perusahaan dalam mengelola modal kerjanya dapat diukur menggunakan rasio working capital turnover (perputaran modal kerja). Menurut Munawir (2004) rasio ini menunjukkan berapa kali dana yang tertanam dalam modal kerja berputar dalam satu periode atau jumlah penjualan yang bisa dicapai oleh setiap rupiah modal kerja dan jumlah penjualan tersebut otomatis berpengaruh terhadap profitabilitas. Apabila rasio working capital turnover semakin besar, maka semakin cepat perputaran modal kerja yang berarti semakin efektif pula pengelolaan sebuah perusahaan terhadap modal kerjanya yang akan berdampak pada peningkatan profitabilitas perusahaan dan pengelolaan cash perusahaan. Pengelolaan cash yang baik akan berdampak positif bagi perusahaan.

Pada dasarnya cash merupakan bagian dari aktiva lancar (current assets), bersama dengan piutang (account receivable) dan persediaan (inventory). Ketiga akun tersebut merupakan bagian dari modal kerja perusahaan dan besarnya jumlah modal kerja tidak terlepas dari motif transaksi, dan motif spekulasi. Komponenkomponen modal kerja tersebut menjamin kontinuitas dan likuiditas perusahaan, sehingga operasi perusahaan akan berjalan dengan ekonomis dan efisien. Hasil penjualan yang tinggi, perusahaan akan mendapatkan keuntungan yang semakin meningkat. Jumlah keuntungan yang diperoleh secara teratur merupakan salah satu faktor yang penting untuk menilai profitabilitas. Kegiatan bisnis yang paling penting untuk kelangsungan operasional perusahaan adalah menjaga ketersediaan modal kerja dan siklus konversi kas (Cash Conversion Cycle) agar tetap memberikan keuntungan demi menjaga produksi yang berkesinambungan.

Siklus Konversi Kas (Cash Conversion Cycle) adalah salah satu pengukuran dari WCM (Working Capital Managemen) yang merupakan jangka waktu yang dibutuhkan perusahaan sejak bahan baku yang di beli dibayarkan hingga piutang usaha dari penjuaalan barang tertagih. Cash Conversion Cycledapat dikatakan sudah cukup untuk memperkuat keputusan pendanaan jangka pendek terutama untuk mengetahui bagaimana kebijakan yang dilakukan perusahaan dalam rangka memenuhi kesenjangan kas, apakah dengan menahan pembayaran utangnya ataukah dengan mempercepat periode penagihan piutangnya. CCC digunakan untuk mengukur berapa lama perusahaan dapat mengumpulkan kas yang berasal dari hasil operasi perusahaan yang pada akhirnya akan mempengaruhi jumlah dana yang diperlukan untuk disimpan pada current assets (aktiva lancar). Keadaan ini tentunya akan mempengaruhi manajemen aset dan liabilitas pada perusahaan tersebut yang bergantung kepada profitabilitas perusahaan. Profitabilitas perusahaan akan senantiasa memiliki hubungan dengan (CCC) yang dapat menunjukkan kepada perusahaan berapa lama jangka waktu yang dibutuhkannya untuk mengubah atau mengembalikan kas keluar yang digunakan untuk kegiatan operasional menjadi kas masuk. Cash Conversion Cycle merupakan alat yang penting dalam menaksir seberapa baik 
kinerja perusahaan dalam mengelola modal kerjanya (Keown, 2010).

Penelitian ini didasarkan pada penelitian yang dilakukan oleh (Enqvist et al., 2014) yang membahas dampak dari manajemen modal kerja pada profitabilitas siklus bisnis dengan objek penelitian perusahaan yang ada di Finlandia. Hasil penelitian tersebut menyatakan bahwa Cash Conversion Cyclemenunjukkan bukti bahwa perusahaan dapat mencapai profitabilitas yang lebih tinggi dengan mengelola persediaan secara efisien dan pemberian batas waktu penagihan piutang perusahaan. Penelitian ini juga mendapatkan hasil bahwa efektifitas manajemen yang didasarkan pada modal kerja merupakan komponen yang memiliki efek signifikan terhadap profitabilitas dari perusahaan.

Penelitian ini dilakukan di negara Finlandia danPenelitian ini juga didasarkan pada penelitian yang dilakukan di Indonesia oleh Suryaputra dan Christiawan (2016) yang membahas bagaimana pengaruh manajemen modal kerja, real estate yang terdaftar di Bursa Efek Indonesia (BEI) tahun 2010-2014. Hasil penelitian ini menunjukkan bahwa pertumbuhan penjualan (PP) terbukti berpengaruh signifikan terhadap ROA, Manajemen modal kerja yang diproksikan ke dalam cash conversion cycle, dan ukuran perusahaan (size) tidak terbukti berpengaruh signifikan terhadap ROA pada perusahaan properti dan real estate yang terdaftar di Bursa Efek Indonesia (BEI) tahun 2010-2014. Implikasi penelitian ini mendukung teori analisis DuPont.

Perbedaan antara penelitian ini dengan penelitian sebelumnya adalahpenelitian ini akan membahas bagaimana kinerja CCC dan hubungannya dengan ukuran perusahaan dan profitabilitas yang diperoleh perusahaan berdasarkan laporan keuangan perusahaan manufaktur yang terdaftar di Bursa Efek Indonesia (BEI) pada tahun pelaporan 20132015.Berdasarkan analisis ini maka peneliti akan mendapatkan hasil signfikansi dari seluruh data yang diolah kemudian akan dibandingkan. Tujuannya adalah untuk menghasilkan generalisasi hasil dari penelitian sebelumnya. Peneliti berkeyakinan bahwa akan terdapat perbedaan hasil apabila penelitian ini didasarkan kepada pengukuran modal kerja yang diproksikan dengan Cash Conversion Cycle dengan variabel pengukur yaitu ukuran perusahaan dan profitabilitas perusahaan, sehingga peneliti tertarik untuk mengambil penelitian yang berjudul "Pengaruh Ukuran dan Cash Conversion Cycle terhadap Profitabilitas Perusahaan"

\section{KAJIAN LITERATUR DAN PENGEMBANGAN HIPOTESIS}

\subsection{Teori Keagenan (Agency Theory)}

Jensen \& Meckling (1976) menjelaskan hubungan keagenan di dalam teori agensi bahwa perusahaan merupakan kumpulan kontrak (nexus of contracts) antara investor dan manajer yang mengurus penggunaan dan pengendalian sumber daya perusahaan. Hubungan keagenan ini mengakibatkan dua permasalahan yaitu: Pertama, terjadinya informasi asimetris, dimana manajer secara umum memiliki lebih banyak informasi mengenai posisi keuangan dan kondisi perusahaan yang sebenarnya. Kedua, terjadinya konflik kepentingan akibat ketidaksamaan tujuan, dimana manajer tidak selalu bertindak sesuai dengan kepentingan investor.

\subsection{Teori Sinyal (Signal Theory)}

Signal dalam bahasa Inggris memiliki arti tanda, atau isyarat. Pada teori sinyal, signal merupakan cara perusahaan dalam memberikan sinyal atau pertanda kepada para pengguna informasi yang diungkapkan perusahaan. Teori sinyal merupakan teori yang menunjukkan bahwa setiap organisasi akan berusaha untuk menunjukkan sinyal positif berupa informasi kepada para penggunainformasi atau stakeholder (Oliveira et al., 2006).

\subsection{Ukuran Perusahaan}

Ukuran perusahaan adalah ukuran atas besarnya aset yang dimiliki oleh perusahaan di mana perusahaan yang besar umumnya memiliki total aset yang besar pula (Sunarto \& Budi, 2009). Ukuran perusahaan dapat berperan penting dalam ekonomi dunia saat ini (Abiodun, 2013). Hal ini dilihat dalam menentukan hubungan perusahaan dengan lingkungan di luar perusahaan, contohnya pertumbuhan perusahaan multinasional dalam 
ekonomi saat ini, mencerminkan pentingnya ukuran perusahaan dalam lingkungan bisnis (Abiodun, 2013).

\subsection{Cash Conversion Cycle (CCC)}

Kemampuan perusahaan dalam mengelola modal kerja mereka selalu berubahubah. Berdasarkan hal tersebut maka timbul keperluan perusahaan untuk mengukur semua keefektifannya. Salah satu metode yang banyak digunakan saat ini untuk mengevaluasi manajemen modal kerja perusahaan yang efektif adalah menggunakan pendekatan bahwa sasaran perusahaan dapat meminimalkan modal kerja yang rentan terhadap pembatas yaitu perusahaan memiliki modal kerja yang cukup untuk mendukung operasinya. Menurut Keown (2010: 245) modal kerja yang minimum dapat dicapai dengan menagih secara cepat kas dari penjualan, meningkatkan perputaran persediaan, dan menurunkan pengeluaran tunai. Semua faktor ini dapat digabungkan ke dalam ukuran tunggal yang disebut siklus perubahan kas (cash conversion cycle). Gitman dan Zutter (2012: 601) mendefinisikan cash conversion cycle sebagai "the length of time required for a company to convert cash invested in its operations to cash received as a result of its operations". Keown (2010) mengemukakan bahwa cash conversion cycle (CCC) merupakan penjumlahan sederhana dari jumlah hari piutang (DSO) dan jumlah hari penjualan persediaan (DSI) dikurangi jumlah hari pembayaran yang belum diselesaikan (DPO).

\subsection{Profitabilitas}

Profitabilitas merupakan salah satu pengukuran kinerja perusahaan yang dapat diukur dalam rasio untuk menggambarkan kemampuan perusahaan dalam menghasilkan laba melalui semua kemampuan dan sumber daya yang dimiliki perusahaan seperti kegiatan penjualan, kas, modal, jumlah karyawan, jumlah cabang, dan sebagainya. Rasio profitabilitas digunakan untuk mengukur efektivitas manajemen secara keseluruhan berdasarkan besarnya laba yang diperoleh sebagai hasil pengembalian atas modal kerja, penjualan, dan investasi yang dinyatakan dalam bentuk persentase. Profitabilitas dapat menunjukkan seberapa baik prospek perusahaan dalam mempertahankan kelangsungan hidupnya ataupun mengembangkan usahanya di masa yang akan datang. Semakin tinggi tingkat rasio profitabilitas suatu perusahaan, maka akan semakin baik perusahaan tersebut dalam menghasilkan laba yang menandakan prospek perusahaan dalam mempertahankan kelangsungan hidupnya serta mengekspansi usahanya semakin baik. Perusahaan yang memiliki prospek cerah tentu akan menarik minat para investor menanamkan modalnya di perusahaan tersebut pula.

\subsection{Pengembangan Hipotesis}

\subsubsection{Pengaruh ukuran perusahaan terhadap profitabilitas}

Ukuran perusahaan adalah ukuran atas besarnya aset yang dimiliki oleh perusahaan, di mana perusahaan yang besar umumnya memiliki total aktiva yang besar pula (Sunarto \& Budi, 2009). Menurut Sunarto \& Budi (2009), perusahaan yang besar lebih mudah untuk mengakses pasar dan memperoleh sumber pendanaan eksternal. Dengan akses yang lebih banyak dan lebih mudah ke sumber daya yang ada, maka perusahaan dapat memenuhi kebutuhannya seperti membeli aset, melakukan investasi, memperoleh pinjaman, dan lain sebagainya. Melalui akses yang lebih banyak ke sumber daya yang ada, kesempatan perusahaan untuk menyediakan kebutuhan konsumen lebih banyak, bahkan memiliki pangsa pasar yang lebih luas, sehingga kesempatan untuk mendapatkan keuntungan pun lebih besar (Doğan, 2013). Ukuran perusahaan memiliki hubungan positif terhadap profitabilitas didukung oleh Serrasqueiro (2009), Abiodun (2013), Doğan (2013), Ehi-Oshio, Adeyemi \& Enofe (2013), dan Yazdanfar (2013).

H1: Ukuran perusahaan berpengaruh terhadap Profitabilitas 


\subsubsection{PengaruhCash Conversion Cycle (CCC) terhadapProfitabilitas}

Laba menjadi indikator penting bagi perusahaan dalam mempertahankan perusahaannya bersaing dalam lingkungan yang kompetitif (Shosa, 2014). Profitabilitas merupakan hubungan antara pendapatan dan biaya yang dihasilkan dengan menggunakan asset perusahaan baik saat ini maupun tetap dalam kegiatan produktif. Sebuah perusahaan dapat meningkatkan keuntungan dengan meningkatkan pendapatan atau mengurangi biaya (Gitman \& Zutter, 2015). Untuk menghasilkan profitabilitas yang tinggi maka diperlukan manajemen modal kerja yang baik dan benar agar perusahaan dapat berjalan dengan baik dan memaksimalkan profitabilitas (Rahimi et al., 2015). Menurut Gitman dan Zutter (2015) salah satu pengukuran dari modal kerja adalah Siklus Konversi Kas (CCC), yaitu jangka waktu lamanya yang dibutuhkan oleh perusahaan untuk mengkonversi kas yang diinvestasikan dalam kegiatan operasional kepada kas yang diterima sebagai bagian dari kegiatan operasional perusahaan. Siklus Konversi Kas (CCC) terdiri dari persediaan (Days of Inventory) merupakan periode yang dibutuhkan untuk mengubah persediaan menjadi penjualan, piutang (Days in Account Receivable Period) merupakan periode yang dibutuhkan pengumpulan piutang dari pelanggan dan hutang (Days in Account Payable Period) merupakan periode yang dibutuhkan untuk membayar kewajiban kepada supplier.

Pengukuran manajemen modal kerja pada umumnya menggunakan siklus konversi (CCC) yaitu jangka waktu antara pengeluaran kas untuk sumber daya dan penerimaan kas dari penjualan produk. Menurut Shin dan Soenen (1998) bahwa ada pengaruh antara CCC dan profitabilitas perusahaan secara ceteris paribus, semakin panjang siklus konversi kas akan merugikan profitabilitas perusahaan. Rahimi et al., (2015) meneliti bahwa ada pengaruh negative siklus konversi kas (CCC) terhadap profitabilitas. Namun demikian yang dilakukan oleh Ponsian et al., (2015) menemukan bahwa ada pengaruh positif (CCC) terhadap profitabilitas.
Berdasarkan uraian diatas maka dapat disusun hipotesis:

H2: Profitabilitas perusahaan berpengaruh positif terhadap Cash Conversion Cycle (CCC)

\subsection{Kerangka Pemikiran}

Berdasarkan keempat hipotesis diatas, berikut ini adalah kerangka pemikiran yang dibentuk dalam penelitian ini:

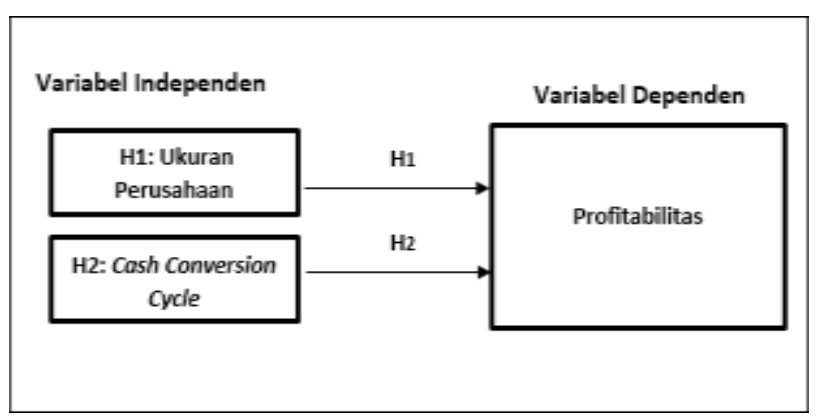

\section{Gambar 1 \\ Kerangka pemikiran}

\section{METODE PENELITIAN}

\subsection{Data dan Sampel}

Populasi dari penelitian ini adalah perusahaan-perusahaan yang terdaftar di Bursa Efek Indonesia (BEI) pada tahun 2013-2015, yaitu sebanyak 399 perusahaan. Sampel ditentukan secara non-probabilitas atau nonrandom dengan menggunakan metode purposive sampling yaitu memilih sampel secara sengaja sesuai persyaratan sampel yang diinginkan.

Penelitian ini menggunakan data sekunder berupa laporan keuangan tahunan yang terdaftar di Bursa Efek Indonesia (BEI) periode 20132015. Sampel yang digunakan sebanyak 261 perusahaan yang memenuhi kriteria yang ditentukan. Kriteria yang digunakan untuk memilih sampel adalah sebagai berikut: pertama terdaftar di Bursa Efek Indonesia (BEI) selama periode penelitian 2013-2015. Kedua, data yang dibutuhkan tersedia dengan lengkap dan menerbitkan laporan keuangan yang telah di audit oleh auditor independen dari tahun 2013-2015. Terakhir, menggunakan periode laporan 
keuangan mulai 1 januari sampai dengan 31 desember dan mata uang rupiah.

\subsection{Variabel Penelitian Pengukurannya} dan

\subsubsection{Variabel Dependen}

\section{a. Profitabilitas}

Profitabilitas perusahaan pada penelitian ini didasarkan pada Return on Assets (ROA). Dimana ROA merupakan rasio untuk mengukur kemampuan perusahaan dalam memaksimalkan keuntungan dengan menggunakan seluruh aktiva yang dimilikinya (Butt, 2014). Dihitung dengan rumus sebagai berikut:

\section{ROA $=$ Net income $/$ Total Assets}

\subsubsection{Variabel Independen}

\section{a. Ukuran perusahaan}

Ukuran perusahaan adalah ukuran atas besarnya aset yang dimiliki oleh perusahaan di mana perusahaan yang besar umumnya memiliki total aktiva yang besar pula (Sunarto \& Budi, 2009). Apabila aktiva perusahaan besar maka akan mempengaruhi nominal aktiva lancar yang akan diinvestasikan bagi kinerja Cash Conversion Cycle (CCC). Ilustrasi tersebut dapat dihitung dengan rumus sebagai berikut:

Ukuran perusahaan $=$ Log dari total asset

\section{b. Cash Conversion Cycle (CCC)}

Cash Conversion Cycle (CCC) adalah adalah jumlah waktu atau lama terikatnya sumber daya perusahaan (Gitman, 2003). Dihitung dengan rumus sebagai berikut:

$$
\mathrm{CCC}=\mathrm{AAI}+\mathrm{ACP}-\mathrm{APP}
$$

Keterangan:

$\mathrm{CCC}=$ Cash conversion cycle (siklus konversi kas)

$\mathrm{AAI}=$ Average age of inventory (periode perputaran persediaan dalam hari)

$\mathrm{ACP}=$ Average collection period (periode ratarata pengumpulan piutang usaha)
$\mathrm{APP}=$ Average payment period (periode rata-rata pembayaran utang usaha)

Di mana penjelasan dari ketiga indikator tersebut adalah sebagai berikut:

Periode perputaran persediaan dalam hari merupakan lamanya persediaan disimpan sebelum dijual (Sugiono, 2009). Ini menunjukkan berapa hari persediaan berada di dalam perusahaan. Dihitung dengan rumus sebagai berikut:

Average age of inventory $=360 /$ Inventory turnover

Inventory turnover dapat dihitung melalui:

Inventory turnover $=$ Cost of good sold $/$ Average inventory

Periode rata-rata pengumpulan piutang usaha merupakan lamanya piutang usaha dapat tertagih, atau berapa lama waktu yang dibutuhkan oleh perusahaan untuk mengubah piutang menjadi uang tunai (Sugiono, 2009). Dihitung dengan rumus sebagai berikut:

Average collection period $=360 /$ Account receivable turnover

Account receivable turnover dapat dihitung melalui:

Account receivable turnover $=$ Sales $/$ Average account receivable

Periode rata-rata pembayaran utang usaha menunjukkan berapa lama utang usaha dilunasi oleh perusahaan (Sugiono, 2009). Dihitung dengan rumus sebagai berikut:

Average payment period $=360 /$ Account payable turnover

Account payable turnover dapat dihitung melalui:

Account payable turnover $=$ Cost of good sold/Average account payable

\subsubsection{Pengujian Hipotesis}

Untuk pengujian hipotesis, penelitian ini menggunakan analisis multiple regression. Adapun persamaan regresi berganda adalah: 
Pengujian hipotesis menggunakan model penelitian:

$$
\mathrm{PP}=a+\beta 1 \mathrm{UP}+\beta 2 C C C+\varepsilon
$$

Keterangan:

$$
\begin{aligned}
& \mathrm{CCC}=\text { Cash Conversion Cycle }(\mathrm{CCC}) \\
& \alpha \quad=\text { konstan } \\
& \mathrm{UP} \quad=\text { ukuran perusahaan } \\
& \mathrm{PP} \quad=\text { Profitabilitas perusahaan } \\
& \varepsilon \quad=\text { error term }
\end{aligned}
$$

\begin{tabular}{|c|c|c|c|c|}
\hline Kriteria Sampel & 2013 & 2014 & 2015 & Total \\
\hline Menerbitkan Laporan Keusngan & 133 & 133 & 133 & 399 \\
\hline Dakam Mats Uang Asing & (34) & (34) & [3a] & $(102)$ \\
\hline Tidak Memuat informasi yang dibutuhkan & (5) & (9) & (6) & (19) \\
\hline \multicolumn{5}{|l|}{ Laporan keuangan yang berakhir tidak pada 31} \\
\hline Desember & (3) & (3) & (4) & (10) \\
\hline Laporan Keuangan tidst kebaca (Buram\}. & (4) & (1) & (2) & (7) \\
\hline Jumlah Sampel & 87 & 87 & 87 & 261 \\
\hline
\end{tabular}

\section{HASIL DAN PEMBAHASAN}

Populasi yang digunakan dalam penelitian ini berjumlah 399 perusahaan manufaktur yang tercatat di IDX dari 2013-2015 (Tabel 1).

Tabel 1. Jumlah Sampel

Setelah dilakukan seleksi atas populasi untuk menentukan sampel akhir berdasarkan kriteria yang telah ditentukan, maka diperoleh 261 perusahaan sebagai sampel dengan menggunakan metode purposive sampling.

\subsection{Statistik Deskriptif}

Pada tabel 2 dijelaskan bahwa jumlah data yang digunakan dalam penelitian ini adalah 261 perusahaan. Variable Independen pada penelitian ini yaitu ukuran perusahaan dan Cash Conversion Cycle. Ukuran perusahaan diperoleh dari laporan posisi keuangan perusahaan dengan nilai rata-rata 28.1714, standar deviasi 1,6597, Minimum 23,4213 dan maksimum 34,4213. Cash Conversion Cycle diperoleh dari laporan posisi keuangan perusahaan dengan nilai rata-rata 5.0560, standar deviasi 1.6814, minimum -1.9556

\begin{tabular}{|c|c|c|c|c|c|}
\hline Variabel & $\mathrm{N}$ & Minimum & Maximum & Mean & Std. Deviation \\
\hline Ukuran Perusahaan & $26 !$ & 23.4213 & 34.3697 & 28.1714 & 1.5597 \\
\hline Cach Conversion Cycle & 261 & 43556 & 125829 & 50560 & t 6514 \\
\hline Profitabilitas & 261 & 13496 & 22625 & 1770 & .1223 \\
\hline
\end{tabular}
dan maksimum 12.5829. Variabel dependen pada penelitian ini yaitu profitabilitas dengan nilai rata-rata 1.7750 , standar deviasi 0.1243 , minimum 1.3496 dan maksimum 2.2825.
Tabel 2. Statistik Deskriptif

\subsection{Hasil Pengujian Hipotesis}

Pengujian hipotesis pada penelitian ini menggunakan analisis regresi berganda dan uji parsial. Sebelum analisis regresi berganda, telah dilakukan pengujian asumsi klasik yang meliputi uji normalitas, uji multikolinearitas dan uji heteroskedastisitas. Analisis regresi berganda digunakan untuk mengetahui hubungan antara variabel independen dan variabel dependen. Uji parsial digunakan untuk menguji signifikansi hubungan antara variabel $\mathrm{X}$ dan $\mathrm{Y}$, apakah variable ukuran perusahaan dan cash conversion cycle (ccc) $(\mathrm{X})$ benar-benar berpengaruh terhadap variabel profitabilitas (Y) secara terpisah atau parsial.

\subsection{Hasil Uji F (Simultan)}

Pembuktian hipotesis secara simultan untuk mengetahui pengaruh semua variabel independen yang digunakan dalam model regresi secara bersama-sama terhadap variabel dependen yang diuji pada tingkat signifikansi 5\%. Jika nilai probability $\mathrm{F}$ lebih kecil dari 0,05 maka hipotesis tidak dapat ditolak. Berikut hasil uji signifikansi

\begin{tabular}{|c|c|c|}
\hline \multicolumn{3}{|c|}{$\begin{array}{c}\text { Hasil Pengujian Pengaruh Ukuran Perusahaan dan Cash Conversion Cycle } \\
\text { Terhadap Profitabilitas }\end{array}$} \\
\hline Model & $f$ & Sig. \\
\hline Aegression & 11.386 & $0.000^{* \cdots}$ \\
\hline Adjusted R Square & & 0.103 \\
\hline N & & 261 \\
\hline p-votue(f-stotistics) & & $0.000 * 2$. \\
\hline
\end{tabular}
simultan variabel dependen intellectual capital dan manajemen laba yang dapat dilihat pada tebel 4.

\section{Tabel 3. Uji Signifikansi Simultan (Uji Statistik F)}

Pada tabel 3 menunjukkan uji statistik F memiliki nilai probability sebesar $0.000<0.05$ jadi dapat 
disimpulkan bahwa seluruh variabel independen yaitu ukuran perusahaan dan cash conversion cycle secara simultan mempengaruhi variabel dependen yaitu profitabilitas.

\subsection{Hasil Uji t (Parsial)}

Pembuktian hipotesis secara parsial bertujuan untuk menguji pengaruh dari variabel independen yaitu ukuran perusahaan dan cash conversion cycle (ccc) terhadap variabel dependen yaitu profitabilitas. Berikut hasil uji yang dapat dilihat pada tabel 4. Uji Signifikansi Parameter Individual (Uji Statistik t).

\section{Tabel 4. Uji Signifikansi Parameter Individual (Uji Statistik T)}

\begin{tabular}{|c|c|c|c|c|c|}
\hline Variabed & B & thitung & Sig. & vif & ü̈̈ giejser \\
\hline Konstenta & 2.748 & 12.641 & 0.000 & & 0.641 \\
\hline Ukutan Perwsehsson & 00002 & 0.67 & ocoss & 1026 & 0.832 \\
\hline Cash Conwersion Cyde & 0.017 & 1802 & $0.094 * *$ & 1026 & $3.06:$ \\
\hline Asquare & & & & & 0.120 \\
\hline Adiusted $R$ squred & & & & & 0.103 \\
\hline
\end{tabular}

Berdasarkan pada data diatas hasil uji t (parsial) sebagai berikut:

variabel Cash Conversion Cycle (X2) berpengaruh terhadap profitabilitas, sedangkan ukuran perusahaan (X1) tidak berpengaruh terhadap profitabilitas. Hal tersebut dapat dilihat dari nilai probabilitas yang dihasilkan variabel Cash Conversion Cycle (X2) sebesar 0,000 yang lebih kecil dari 0,05 dan nilai probabilitas yang dihasilkan variabel ukuran perusahaan (X1) sebesar 0.638 yang lebih besar dari 0,05 .

Tabel 5. Kesimpulan Hipotesis

\begin{tabular}{|c|c|c|c|}
\hline Hipotesis & Siz. & $T$ & Hasil \\
\hline $\begin{array}{l}\text { H1 : Ukiuran perusahaanberpengaruh } \\
\text { terhadap prafitabilitas }\end{array}$ & 0.038 & 0.471 & $\begin{array}{l}\text { Tidak } \\
\text { Terdukang }\end{array}$ \\
\hline $\begin{array}{l}\text { H2: Cash Conversion Cycle berpengaruh } \\
\text { terhadap prafitabiltas }\end{array}$ & $0.034 * 0$ & 1.802 & Terdukung \\
\hline *Senfikan pado level $M \pi$ & & & \\
\hline
\end{tabular}

\subsection{Pembahasan Penelitian}

Penelitian ini bertujuan untuk meneliti pengaruh ukuran perusahaan dan cash conversion cycle (ccc) (X) terhadap variabel profitabilitas (Y).

\section{Pengaruh ukuran perusahaan terhadap profitabilitas}

Berdasarkan hasil uji statistik yang telah diuraikan pada tabel 4 menunjukkan bahwa tidak terdapat pengaruh menunjukkan bahwa tidak terdapat pengaruh antara ukuran perusahaan terhadap profitabilitas. Hal ini menandakan bahwa suatu perusahaan tidak bisa dilihat hanya pada ukurannya saja. Perusahaan yang besar belum tentu bisa memperoleh profitabilitas yang besar begitu juga sebaliknya perusahaan kecil belum tentu menghasilkan profitabilitas yang kecil. Selain itu salah satu alasan mengapa ukuran perusahaan tidak berpengaruh terhadap profitabilitas adalah tingkat efisiensi Operasional, bisa saja terjadi pada perusahaan yang besar dengan aset yang besar pula namun efisiensi operasional nya tidak berjalan dengan baik, selain itu juga perusahaan melakukan investasi yang kurang tepat dapat menjadi salah satu aspek mengapa tidak terdapat pengaruh. Hasil ini konsisten dengan penelitian Putri et al (2015) dan Rikalmi dan Wibowo (2016) yang menguji tentang pengaruh ukuran perusahaan dan modal kerja terhadap profitabilitas perusahaan.

\section{Pengaruh Cash Conversion Cycle terhadap Profitabilitas}

Berdasarkan hasil uji statistik yang telah dijelaskan pada table 4 menunjukkan bahwa terdapat pengaruh antara Cash Conversion Cycleterhadap profitabilitas. Hal ini menandakan bahwa semakin baik perusahaan dalam mengelola perputaran kas maka semakin baik profitabilitas yang diperoleh. perusahaan dan sebaliknya. Hasil ini konsisten dengan penelitian Putri et al (2015) dan Wibowo dan Rikalmi (2016) yang menguji tentang pengaruh ukuran perusahaan dan modal kerja terhadap profitabilitas perusahaan.

Hasil ini tidak konsisten dengan Aregbeyen (2013) yang menguji pengaruh modal kerja terhadap profitabilitas hasilnya bahwa tidak terdapat pengaruh antara modal kerja terhadap profitabilitas perusahaan. 


\section{SIMPULAN DAN SARAN}

\subsection{Simpulan}

Berdasarkan hasil penelitian mengenai ukuran perusahaan dan cash conversion cycle terhadap profitabilitas perusahaan yang terdaftar di Bursa Efek Indonesia (BEI) periode 2013-2015. Dari dua hipotesis yang dijabarkan satu hipotesis terdukung dan satu hipotesis tidak terdukung. Kesimpulan dari penelitian ini adalah sebagai berikut:

a. Ukuran perusahaan tidak berpengaruh terhadap profitabilitas perusahaan dikarenakan besar atau kecilnya perusahaan tidak hanya tergantung pada ukuran perusahaan

b. Cash Conversion Cycle berpengaruh terhadap profitabilitas perusahaan dikarenakan

\subsection{Keterbatasan dan Saran}

Penelitian ini mempunyai keterbatasan baik dalam pengambilan sampel maupun dalam pengukuran variabel. Beberapa keterbatasan dalam penelitian ini antara lain: pertama, dalam penelitian ini penulis hanya menggunakan sampel selama 3 tahun. Kedua, Penulis hanya menggunakan dua variabel independen yakni ukuran perusahaan dan cash conversion cycle dan satu variabel dependen yakni profitabilitas perusahaan.

Berdasarkan keterbatasan yang terdapat dalam penelitian ini, maka penulis mengusulkan beberapa saran untuk penelitian sejenis selanjutnya, yaitu: pertama, Penelitian selanjutnya sebaiknya menambah jumlah sampel dan periode sampel sehingga jumlah sampel akan bertambah lebih banyak dari sebelumnya. Kedua, Penelitian selanjutnya sebaiknya menambahkan variabel-variabel independen lainnya seperti umur perusahaan, leverage, dan sebagainya.

\section{DAFTAR PUSTAKA}

Abiodun, B. Y. (2013). The Effect of Firm Size on Firms Profitability in Nigeria. Journal of Economics and Sustainable Development, 4(5), 90-94.
Ahmad, K. (2002). Dasar - Dasar Manajemen Modal Kerja, Cetakan Pertama. Jakarta: Rineka Cipta.

Anser, R. d. (2013). "Cash Conversion Cycle and Firm "s Profitability - A Study Listed Manufacturing Companies od Pakistan". IQSR Journal of Business and Management Vol. 8, Issue 2.

Barber, B. L. (1996). Detecting abnormal operating performance: the empirical power and specification of test statistics. J. Financial Economics 41 (3), PP. 359399.

Braun, M. L. (1983). Finance and the business cycle: international, inter-industry evidence. J. Finance 60 (3), 1097-1128.

Erlina. (2011). Metodologi Penelitian. Medan: USU Press.

Garcia-Teruel, P. M.-S. (2007). Effects of working capital management on SME profitability. Int. J. ManagerialFinance 3 (2), 164-177.

Ghozali, I. (2009). “Aplikasi Multivariate dengan Program SPSS". Semarang: Badan Penerbit Universitas Dipenegoro.

Gill, A. B. (2010). The relationship between working capital management and profitability: evidence from theUnited States. Business Economics J. 10, 1-9.

Gitman, L. (1987). Basic Managerial Finance. New York: Harper \& Row.

Harford, J. (1999). Corporate cash reserves and acquisitions. J. Finance 54, 1969-1997.

Harford, J. M. (2008). Corporate governance and firm cash holdings. J. Financial Economics 87 (3), , 535-555.

Hermuningsih, S. (2012). Pengaruh Profitabilitas, SIZE terhadap nilai perusahaan dengan struktur modal sebagai variabel intervening. Jurnal siasat bisnis , 232242.

Kamath, R. (1989). How useful are common liquidity measures? J. Cash Manage. 9 (1), 24-28.

Abiodun, B. Y. (2013). The Effect of Firm Size on Firms Profitability in Nigeria. Journal of Economics and Sustainable Development, 4(5), 90-94. 
Ahmad, K. (2002). Dasar - Dasar Manajemen Modal Kerja, Cetakan Pertama. Jakarta: Rineka Cipta.

Anser, R. d. (2013). "Cash Conversion Cycle and Firm"s Profitability - A Study Listed Manufacturing Companies od Pakistan". IQSR Journal of Business and Management Vol. 8, Issue 2.

Barber, B. L. (1996). Detecting abnormal operating performance: the empirical power and specification of test statistics.

J. Financial Economics 41 (3), PP. 359- 399.

Braun, M. L. (1983). Finance and the business cycle: international, inter-industry evidence. $J$. Finance 60 (3), 1097-1128.

Erlina. (2011). Metodologi Penelitian. Medan: USU Press.

Garcia-Teruel, P. M.-S. (2007). Effects of working capital management on SME profitability. Int. J. ManagerialFinance 3 (2), 164177.

Ghozali, I. (2009). "Aplikasi Multivariate dengan Program SPSS”. Semarang: Badan Penerbit Universitas Dipenegoro.

Gill, A. B. (2010). The relationship between working capital management and profitability: evidence from theUnited States. Business Economics J. 10, $1-9$.

Gitman, L. (1987). Basic Managerial Finance.

New York: Harper \& Row.

Harford, J. (1999). Corporate cash reserves and acquisitions. $J$. Finance 54, 1969-1997.

Harford, J. M. (2008). Corporate governance and firm cash holdings. J. Financial Economics 87 (3), 535-555.
Hermuningsih, S. (2012). Pengaruh Profitabilitas, SIZE terhadap nilai perusahaan dengan struktur modal sebagai variabel intervening. Jurnal siasat bisnis , 232- 242.

Kamath, R. (1989). How useful are common liquidity measures? $\mathrm{J}$. Cash Manage. 9 (1), 24-28.

Keown, A. M. (2001). Foundations of Finance. (3rd ed.). Upper Saddle River, N.Y: Pearson Education.

Korajczyk, R. L. (2003). Capital structure choice: macroeconomic conditions and financial constraints. $J$. Financial Eco-nomics 68 (1), 75-109.

Moss, J. a. (1993). Cash conversion cycle and firm size: a study of retail firms. Managerial Finance Vol.19, 25-34.

Munawir, S. (2004). Analisis Laporan Keuangan. Yogyakarta: Liberty.

Peel, M. W. (1994). Working capital and financial management practices in the Small Firm sector. nt. Small Business J.14 (2), 52-68.

Sawir, A. (2005). Analisis Kinerja Keuangan dan Perencanaan Keuangan Perusahaan. Jakarta: Gramedia Pustaka Umum.

Sheela, S. C. (2012). Financial Performance of Pharmaceutical Industry in India using DuPont Analysis. European Journal of Business and Management, 4(14), 8491. Sugiono, A. (2009). Manajemen Keuangan Untuk

Praktisi Keuangan. Jakarta: Grasindo.

Sugiyono. (2007). Metodologi Penelitian Bisnis, Cetakan

Kesembilan. Bandung: Alfabeta.

Sugiyono. (2008). "Metodologi Penelitian Bisnis”. Bandung: Alvabeta. 
Sunarto \& Budi, A. P. (2009). Pengaruh Leverage, Ukuran dan Pertumbuhan Perusahaan Terhadap Profitabilitas. Jurnal Ilmiah Telaah Manajemen, 6(1), 86-103.

Syamsuddin, L. (2004). Manajemen Keuangan Perusahaan: Konsep Aplikasi dalam Perencanaan, Pengawasan, dan Pengambilan Keputusan. Jakarta: PT Raja Grafindo Persada.

Syarief, M. E. (2009). Cash Conversion Cycle dan Hubungannya dengan Ukuran Perusahaan, Profitabilitas dan Manajemen Modal Kerja. Jurnal Ekonomi Bisnis, Tahun 14 Nomor 1, Maret 2009.

Uyar, A. (2009). The Relationship of Cash Conversion Cycle with Firm Size and Profitability: An Empirical Investigation In Turkey. International Research Journal of Finance and Economics, 186- 193.

Wang, Y. (2002). Liquidity management, operating performance and corporate value: evidence from Japan and Taiwan. J.Multinational Financial Manage. 12 (2), 159-169. 